\title{
A Study on the Effects of Inflation Rate, Interest Rate, and Exchange Rate on the Performance of Indonesia Sharia Stock Market
}

\author{
Erna Garnia ${ }^{1, *}$ Tahmat $^{2}$, Rizal Deden ${ }^{3,}$ Saeful $\operatorname{Iman}^{4}$
}

\author{
${ }^{1}$ University of Sangga Buana, Bandung, Indonesia \\ ${ }^{2}$ University of Sangga Buana, Bandung, Indonesia \\ ${ }^{3}$ University of Sangga Buana, Bandung, Indonesia \\ ${ }^{4}$ University of Sangga Buana, Bandung, Indonesia \\ ${ }^{*}$ Corresponding author. Email: erna.garnia@usbypkp.ac.id
}

\begin{abstract}
Various macroeconomic factors influence the stock market performance. This study aims to investigate the ef-fects of inflation rate, interest rate, and exchange rate on the sharia stock market performance in the Indonesia Stock Exchange. The market performance is indicated by a portfolio index calculated based on the return of stocks that are consistently listed in the Indonesia Sharia Stock Index (ISSI). The effects of every macroeco-nomic factor are first tested individually and then simultaneously. Based on the data from 2011 up to 2019, it is found that inflation rate, interest rate, and US\$ exchange rate have a negative effect on the market performance.
\end{abstract}

Keywords: Inflation, Interest Rates, Exchange Rates, and Sharia Stocks.

\section{INTRODUCTION}

Indonesia is a country dominated by Muslims. As a Muslim country, sharia-based financial institutions have grown tremendously in the past few decades. Sharia stocks are emerging stocks in Indonesia Stock Exchange. Since the establishment in 2010, the number of sharia stocks has grown to 423 stocks in 2019. In Indonesia Stock Exchange, the Indonesia Sharia Stock Index (ISSI) was established in 2010.

By definition, a stock is considered as sharia stock if:

The business activities of listed companies do not violate sharia principles, such as gambling and the like, prohibited trading, ribawi financial services (interest-based banks and financing companies), risk trading that contains an element of uncertainty (gharar) or gambling (maisir), production or distribution of illicit goods, destroy morals or harm, transactions that contain elements of bribery (risywah).

The financial ratio of the issuer according to Sha-ria, namely total interest-based debt compared to total assets, is not more than $45 \%$, and non-halal income compared to total income is not more than $10 \%$.

There is a special committee that determines a stock can be classified as Sharia or nonsharia stock in Indonesia.

The trading rules for sharia stocks are different from those of non-sharia. The main differences areonly sharia stocks can be transacted, sharia stocks buying transactions can only be done in cash (cash-basis transactions), so there are no margin trading transactions and Prohibition of selling sharia stocks that are not yet owned (short selling). As the trading rules are different, it is expected that stock returns will be different from those of non-sharia, especially regarding the effects of macroe-conomic factors. 
Figure 1 shows IHSG, ISSI, interest rate, inflation rate, and exchange rate during the 2011-2019 peri-od. It can be seen that the IHSG and ISSI in-creased significantly (more than 50\%) during the period. Though the average is almost constant, the inflation rate fluctuated widely during that period. The US\$ exchange rate increased during that peri-od. Though there is a slight variation, the interest rate was almost constant during that period. The significant increase of IHSG and ISSI shows that both sharia and non-sharia stocks in Indonesia Stock Exchange have attracted investors and traded actively. Many studies on the effects of various macroeconomic factors on stock returns have been reported; however, the results are still unclear and inconsistent.

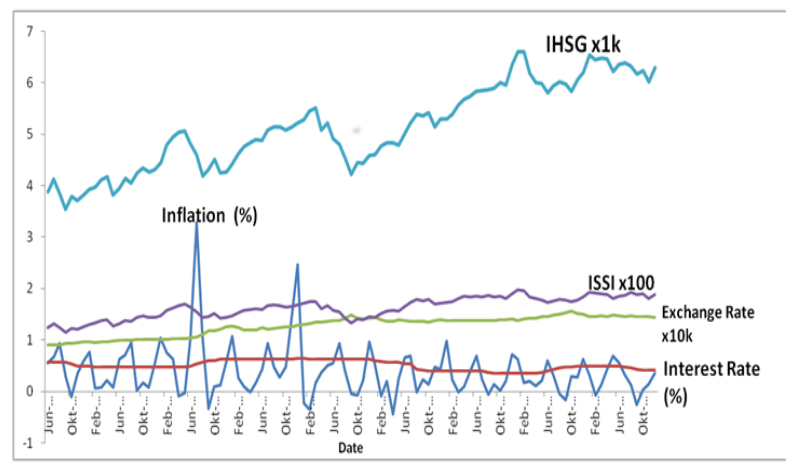

Figure 1. Various macroeconomic factors and market indexes.

This paper studies the effects of macroeconomic factors on the sharia stock market performance in Indonesia Stock Exchange. The market performance is defined as an index calculated from the returns of 46 sharia stocks listed consistently in the Indonesia Sharia Stock Index (ISSI). The studied macroeconomic factors are inflation rate, interest rate, and US\$ exchange rate. Each macroeconomic factor is first tested individually and then tested simultaneously. Based on the data of the 2011-2019 period, it is found that the effects of inflation rate, interest rate, and exchange rate are negative. The main contribution of this paper is a technique to obtaining consistent and significant results.

\subsection{Literature review}

In the past few decades, interests in Islamic finance are growing significantly worldwide. Though many researchers still doubt Islamic finance, many re-searchers expect that Islamic markets and institutions will grow dramatically in the future (Al Zahrani 2019).

Ross initiates research on the effects of macroeconomic factors of stock returns by introducing a theory named Arbitrage Pricing (APT) (Ross 1976). This theory is considered different from the Capital Asset Pricing Model (CAPM) theory introduced by Sharpe in 1964 (Sharpe 1964). In APT, it is hypothetically argued that the stock prices are determined by various macroeconomics variables instead of just market risk proposed in CAPM.

Various studies on the performance of sharia stocks have been reported in the literature (Khazali 2014, Narayan 2016-2018 and Yahyaee 2020). The ef-fects of various global factors on the market perfor-mance have also been reported (Naifar 2016, Maghyereh 2019 and Godil 2020). In Indonesia, sev-eral works on sharia market performances have also been reported (Wahyudi 2014 and Qoyum 2020). Most of the common macroeconomic factors used in these studies are inflation rate, interest rate, exchange rate, gold price, and Gross Domestic Product. Though various works have been done, the authors consider that the results are inconsistent.

\section{RESEARCH METHODS}

The data used in this study is obtained from Indonesia Stock Exchanges over the 20112019 period. The study uses sharia stocks that are consistently listed in ISSI over that period. Though the total number of sharia stocks in 2019 was 423 stocks, there were just 46 stocks consistently listed and actively traded in ISSI. The data for inflation, interest rate, and US\$ exchange rates are obtained from the Indonesian Cen-tral Bank (BI). The interest rate used in this research is BI's 7day Reverse Report. In this paper, a market 
performance index is calculated as the average monthly return of 46 stocks is listed consistently in ISSI.

At first, classical tests such as normality, heterosce-dasticity, multicollinearity, and autocorrelation are conducted. If all classical tests pass, then the effects of inflation rate, interest rate, and exchange rate on the stock return are tested individually. The final work is testing the effects of those three macroeconomic fac-tors simultaneously.

The authors then try several approaches to smooth the data. When the monthly data is used, it is found that the results are inconsistent. It seems that the main reason is the monthly data fluctuates widely from time to time. To solve this problem, this study uses a moving average technique. In this technique, monthly data that is averaging over 12 months is used. The accuracy of the derived model is indicated by the coefficient of determination and significant probability.

\section{RESULTS AND DISCUSSIONS}

Table 1 shows the results of the t-test. This test is re-quired to determine the effects of each independent variable on the dependent variable. This table shows that each macroeconomic factor has a negative effect on the market performance index. The result is statis-tically acceptable because the significant levels are less than 5\% as shown in Table 1.

Table 1: The t-test

\begin{tabular}{lllll}
\hline Variable & Coefficient & Std. Error & t-Statistic & Prob. \\
\hline C & 0.110100 & 0.015005 & 7.337342 & 0.0000 \\
Inflation rate & -4.022181 & 1.248834 & -3.220750 & 0.0018 \\
Interest rate & -5.935490 & 1.834950 & -3.234688 & 0.0017 \\
Exchange rate & -0.037075 & 0.008488 & -4.367836 & 0.0000 \\
\hline
\end{tabular}

Table 2 shows the results of the f-test. This is a test to check the effects of all independent variables on the dependent variable. These results show that the three macroeconomic factors have a substantial impact on the market performance index. As the signif- icant level is less than 5\%, the resulted model is statistically acceptable.

Table 2: F test

\begin{tabular}{ll}
\hline & Weighted Statistics \\
\hline F-statistic & 14.42209 \\
Prob (F-statistic) & 0.000000 \\
\hline
\end{tabular}

Table 3 shows the test results for Rsquared and adjusted values. This test is used to calculate the coef-ficient of determination. This test is useful to check how far the dependent variable is explained by the independent variables (Adjusted R-squared $=30 \%$ ). This value is relatively high as the most commonly obtained value is approximately 10-30\% (Levy 2012).

Table 3: Coefficient of Determination (R2)

\begin{tabular}{lc}
\hline R-squared & 0.317513 \\
Adjusted R-squared & 0.295497 \\
\hline
\end{tabular}

Based on the above results, it can be concluded that inflation rate, interest rate, and exchange rate have a substantial impact on the sharia stock market perfor-mance. The effects of all macroeconomic factors investigated in this work are negative. The biggest ef-fect is the interest rate and the lowest is the exchange rate.

\section{CONCLUSION}

This study investigates the effects of inflation rate, interest rate, and exchange rate on the sharia stock market performance. Based on the data from 2011-2019, it is found that the effects of those macroeco-nomic factors on the market performance are negative. The coefficient of determination is $30 \%$. The results are consistent when each macroeconomic factor is tested individually. Generalization of this result is left for future investigation. 


\section{REFERENCES}

Al-Khazali, O. Lean, H.H. and Samet, A. 2014. Do Islamic stock indexes outperform conventional stock indexes? A stochastic dominance approach. Pacific-Basin Finance Journal (28): 29-46.

Al-Yahyaee, K.H. Mensi, W. Rehman, M.U. and Vo, X.V. 2020. Do Islamic stocks outperform conventional stock sectors during normal and crisis periods? Extreme co-movements and portfolio management analysis. Pacific-basin Finance Journal (62): $1-21$

Al Zahrani, M. 2019. Islamic corporate finance, financial markets, and institutions: An Overview. Journal of Corporate Finance (55): 1-5.

Godil, D.I. Sarwat, S. Sharif, A. and Jermsittiparsert, K. 2020. How oil prices, gold prices, uncertainty, and risk impact Islamic and conventional stocks? Empirical evidence from QARDL technique. Resources Policy (66): 1-9.

Levy, H. 2012. The Capital Asset Pricing Model in The $21^{\text {st }}$ Century. Book, Cambridge University Press. New York.

Maghyereh, A.I. Abdoh, H. and Awartani, B. 2019. Connectedness and hedging between gold and Islamic securities: A new evidence from timefrequency domain approaches. Pacific Basin Finance Journal (54): 13-28.

Naifar, N. 2016. Do global risk factors and macroeconomic conditions affect global Islamic index dynamics? A quantile regression approach. The Quarterly Review of Economics and Finance (61): 29-39.

Narayan, P.K. Phan, D.H.B. Sharma, S.S. and Westerlund, J. 2016. Are Islamic stock returns predictable? A global perspective. Pacific-Basin Finance Journal (40): 210-223.

Narayan, P.K. Phan, D.H.N. Narayan, S. and Bannigidadmad, D. 2017. Is there a financial news risk premium in Islamic stocks?. Pacific-Basin Finance Journal (42): 158-170

Narayan, P.K. 2018. Profitability of technologyinvesting Islamic and non-Islamic stock markets. Pacific-Basin Finance Journal (52): 70-81.

Qoyum, A. Al Hasfi, R.U. Zusryn, A.S. Kusuma, H. and Qizam, I. 2020. Does an Islamic-SRI portfolio really matter? Empirical application of valuation models in Indonesia. Borsa Istanbul Review (20): 1-20.

Ross, S.A. 1976. The Arbitrage Theory of Capital Asset Pricing. The Journal of Economic Theory (13): 341-360.

Sharpe, W.F. 1964. Capital Asset Prices: A Theory of Market Equilibrium under Conditions of Risk. The Journal of Finance 19(3): 425-442.

Wahyudi, I. and Sani, G.A. 2014. Interdependence between Islamic capital market and money market: Evidence from Indonesia. Borsa Istanbul Review (14): 32-47. 